\title{
Efficacy of Ribavirin to Prevent Hepatitis Reactivation in Hepatitis C Virus-infected Patients Treated for Non-Hodgkin Lymphoma
}

\author{
Fouad M Abo-Taleb , Ashraf M El-Hefeni, Ahmed Kotb, Tarek A \\ El-Gohary \\ Medical Oncology and Hematology Department, Faculty of Medicine, Zagazig University, \\ Egypt
}

Corresponding Author
Ahmed Kotb
Mobile:
+201096720645
Email:
abotasnem1@gmail.co
m

Received : $11 / 12$ $/ 2012$

Accepted after revision:4 /2/2013

Key words:

Hepatitis C virus, Ribavirin, NonHodgkin lymphoma, Reactivation
Background and study aims: Reports have found an association between $\mathrm{B}$ cell non-Hodgkin lymphomas (NHL) and Hepatitis C virus (HCV) infection. However, data on acute exacerbation and reactivation of chronic $\mathrm{HCV}$ infection following chemotherapy are very limited. We studied the efficacy of ribavirin to prevent hepatitis reactivation in $\mathrm{HCV}$ infected patients treated for NHL.

Patients and methods: This study was carried out at Medical Oncology \& Hematology Department , Zagazig University Hospitals. It included 57 patients with B-cell NHL who were naïve to chemotherapy, among them 24 patients were positive for $\mathrm{HCV}$ and 33 patients were negative for $\mathrm{HCV}$ (group C). The HCV positive group were subdivided into 11 patients who received ribavirin (group A) and 13 patients did not receive ribavirin (group $\mathrm{B}$ ). Routine investigations for NHL were done, $\mathrm{HCV}$ RNA was measured for $\mathrm{HCV}$ positive patients before and after the end of chemotherapy.

Results: HCV infection occurred in $42 \%$ of patients with B cell NHL. Acute

\section{INTRODUCTION}

Hepatitis C virus (HCV) infection is endemic in Egypt. Many reports have found an association between $\mathrm{B}$ cell non-Hodgkin lymphomas (NHL) and $\mathrm{HCV}$ infection. The role of $\mathrm{HCV}$ infection in lymphomagenesis may be related to chronic antigenic stimulation of $\mathrm{HCV}$ [1]. However, little is known about acute exacerbation and reactivation of chronic $\mathrm{HCV}$ infection in patients with cancer [2]. Most of the reported cases of liver dysfunction in HCVinfected cancer patients occur in nonHodgkin lymphomas [3]. Authors hepatic enzyme exacerbation occurred in $8(14 \%)$ of all patients with the highest percentage was $29.2 \%$ among $\mathrm{HCV}$ infected patients (7/24), while only one patient $(3 \%)$ in the HCV negative group $(\mathrm{p}=0.007)$. Among the $24 \mathrm{NHL}$ patients with $\mathrm{HCV}$ positivity, we compared group A versus group B during chemotherapy as regards to hepatic enzyme flare, it was ( $27 \%$ \& 30\%, respectively, $\mathrm{p}=0.6$ ). Five $(20.8 \%)$ of 24 NHL patients with HCV positivity developed HCV PCR reactivation; 2 patients of group $\mathrm{A}$ and 3 patients of group B $(18.2 \% \& 23.1 \%$, respectively, $\mathrm{p}=0.58$ ). The outcome was comparable between the three groups.

Conclusion: The frequency of $\mathrm{HCV}$ infection in patients with B cell NHL is higher than in the general population. Acute exacerbation and reactivation of chronic HCV infection occur in a sizeable subset of patients with NHL during chemotherapy. The use of ribavirin did not decrease hepatic enzyme flare or $\mathrm{HCV}$ PCR reactivation during chemotherapy.

have reported a reactivation of $\mathrm{HCV}$ replication in patients with $\mathrm{CD} 20$ positive B-cell NHL under Rituximab-based chemotherapy [4].

Also, limited studies indicate that episodes of acute exacerbation of chronic HCV seem to be less severe than similar episodes of chronic hepatitis B virus (HBV) exacerbation [5] As reactivation of the $\mathrm{HBV}$ after cytotoxic chemotherapy is common in clinical practice. Thus, prophylactic antiviral (lamivudine) treatment should be started at the initiation of chemotherapy and maintained for at 
least 6 monthes following the completion of therapy [6].

In our study, in analogy with the use of lamivudine as prophylaxis against $\mathrm{HBV}$ reactivation, we tried to use Ribavirin (a synthetic nucleoside analogue) as a prophylactic antiviral treatment to reduce the risk of $\mathrm{HCV}$ reactivation and severe hepatitis flares.

We sought to determine the frequency of $\mathrm{HCV}$ infection among B cell NHL patients, also to determine the efficacy of ribavirin to prevent hepatitis reactivation in $\mathrm{HCV}$-infected patients treated for NHL.

\section{PATIENTS AND METHODS}

The study is a randomized controlled intervention trial, that was carried out at Medical Oncology and Hematology Department , Zagazig University Hospitals between July 2010 and August 2012. It included 57 patients with NHL who were naïve to chemotherapy, among them 24 patients were positive for $\mathrm{HCV}$ infection \& 33 patients were negative for $\mathrm{HCV}$ infection (group C). The $\mathrm{HCV}$ positive group was subdivided into 11 patients who received ribavirin (group A) and 13 patients without ribavirin (group B) (figure1).

\section{Inclusion criteria:}

1. Age: > 18 years.

2. Sex: Both sexes were eligible.

3. Pathological proof of B-cell non- Hodgkin's lymphoma.

4. Adequate bone marrow reserve.

5. Adequate liver and kidney functions.

6. Eastern Cooperative Oncology Group performance status (PS) of $\leq 2$.

7. All patients were naïve for anti-HCV treatment.

8. All patients were chemotherapy naïve.

\section{Exclusion criteria:}

1. Prior or concurrent second malignancy.

2. Pregnant, lactating females.

3. Medical contraindication for receiving the study treatment as patients with active or uncontrolled infection.

4. Positivity for $\mathrm{HBsAg}$ or $\mathrm{HBcAb}$ or HIV.

5. Non-viral causes of liver affection.

\section{Methods:}

Informed consent was obtained from participants. (females must accept to use contraception during treatment). All participants were subjected to:

1. Thorough history taking, clinical examination.

2. Complete blood counts.

3. Serum Lactate dehydrogenase (LDH).

4. Erythrocyte sedimentation rate (ESR).

5. Liver and Kidney function tests (ALT ,AST ,Serum billirubin, serum albumin, INR and serum Creatinine) .

6. Viral markers (HBs Ag, HBcAb, HCV Abs) and HCV RNA in serum by PCR if $\mathrm{HCV}$ antibodies were positive.

7. Autoimmune antibodies (antinuclear

antibody (ANA), anti-smooth muscle antibody (SMA), liver/kidney microsomal antibody (LKM), anti soluble liver antigen (SLA/LP) and anti-mitochondrial antibody (AMA)).

8. Serum electrolytes ( $\mathrm{Na}, \mathrm{K} \& \mathrm{Ca}$ ), Serum uric acid and fasting blood sugar.

9. Bone marrow Biopsy.

10. Echocardiography and radiological studies were performed including: chest radiograph, CT scans of abdomen and pelvis and CT scans of the neck and thorax if any abnormality is noted or suspected on the routine chest radiograph (for staging).

\section{HCV RNA examination}

HCV RNA in serum was done at the beginning and at the end of chemotherapy. It was quantified using a commercially available polymerase chain reaction method (COBAS TaqMan HCV Test; Roche Molecular Systems, Branchburg, NJ) with a quantification range from 43 to $69,000,000$ $\mathrm{IU} / \mathrm{ml}$ [7].

\section{Treatment plan:}

Chemotherapy were given based on the pathological sub-types either indolent or aggressive NHL. Detailed history, full clinical examination and Laboratory assessment were performed before each treatment cycle. All patients who ended the first 4 cycles of treatment were eligible for reevaluation within 2 to 3 
weeks, and those who responded (complete response $[\mathrm{CR}]$ or partial response $[\mathrm{PR}]$ ) were completed the therapy to a total 6 cycles.

We randomly divided the patients with positive $\mathrm{HCV}$ infection into two groups, one group received Ribavirin 1000- 1200 mg daily orally during the course of chemotherapy and the other did not.

\section{Definitions:}

Acute exacerbation of chronic HCV infection was defined as a 3-fold or greater increase in serum ALT level in the absence of the use of hepatotoxic drugs (other than chemotherapeutics), or other systemic infections (including hepatitis A, HBV and human immunodeficiency virus infections) [5].

$\mathrm{HCV}$ reactivation was defined as an increase in $\mathrm{HCV}$ viral load of at least $1 \log 10 \mathrm{IU} / \mathrm{ml}$ over baseline following chemotherapy or immunosuppressive therapy, as chronically infected patients have stable HCV RNA levels that may vary by $\_.5 \log 10 \mathrm{IU} / \mathrm{ml}[8]$.

\section{Response criteria:}

According to Revised response evaluation criteria in solid tumors (version 1.1) [9].

\section{Statistical Analysis}

All the data were managed using SPSS-version version 20.0. A two-sided $P$ value of less than 0.05 was considered to indicate statistical significance. The association between categorical data was tested by Chi-square and Fisher exact tests. The t-test was used to assess whether the means of two groups were statistically different from each other. To compare between more than two groups, one way analysis of variance (ANOVA) was used. Survival analysis was done according to Kaplan-Meier method, and compared by log-rank test.

Overall survival (OS) was calculated as interval (by months) between date of randomization (pathology date) till date of death or date of last follow up.

Disease free survival (DES) was calculated as the period of time patient lived without evidence of disease relapse (for responding patients). It is the interval (by months) between date of the complete response till date of disease progression or date of last follow up[1].

Figure (1) shows the distribution of the study groups

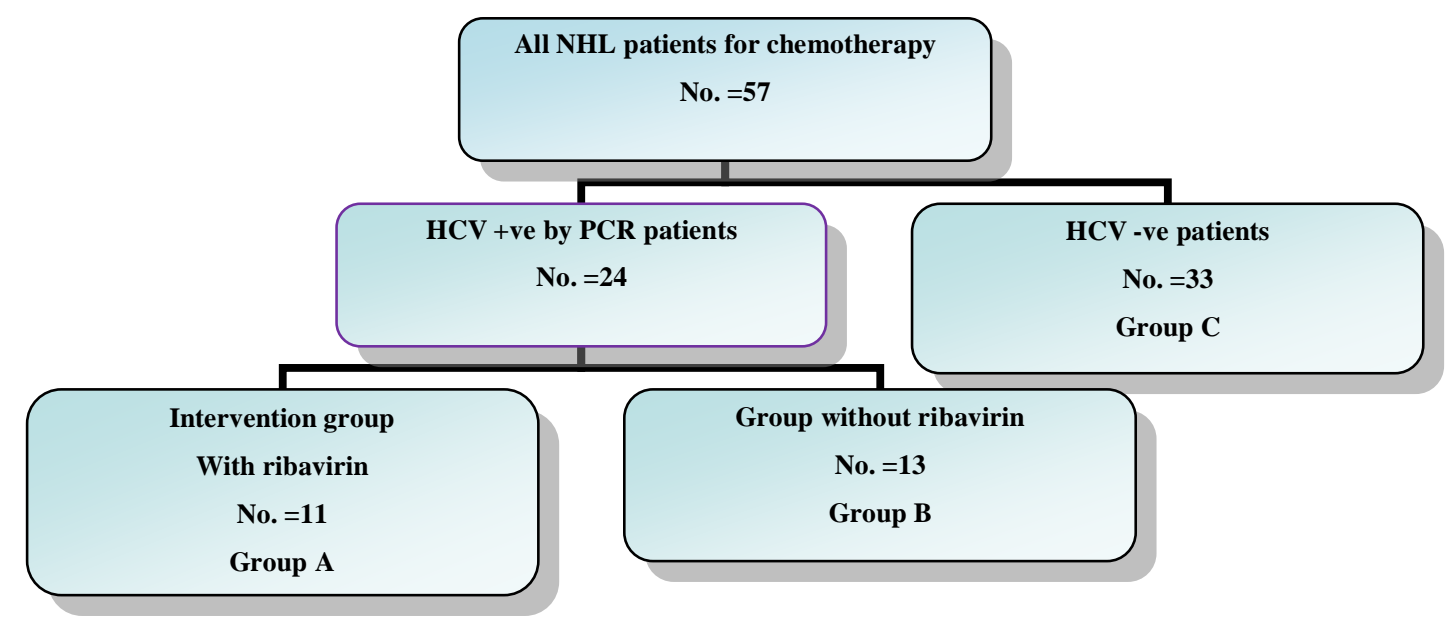




\section{RESULTS}

The base line characters of all patients are described in (table1). In our study, HCV infection occurred in $42 \%$ of patients with B cell NHL. Acute hepatic enzyme exacerbation occurred in $8(14 \%)$ of all patients, and with the highest percentage $(29.2 \%)$ among $\mathrm{HCV}$ infected patients (7/24), while only one patient $(3 \%)$ in the HCV -ve group $(\mathrm{p}=0.007)$. Among the 24 NHL patients with HCV positivity, we compare patients who received ribavirin (group A) versus those who did not receive ribavirin (group B) during chemotherapy as regards to hepatic enzyme flare which was (27\% \& 30\%, respectively, $\mathrm{p}=0.6)$. Five $(20.8 \%)$ of $24 \mathrm{NHL}$ patients with HCV positivity developed HCV PCR reactivation; 2 patients of group A and 3 of group B patients (table 2 and 3 ). There was a significant relation between $\mathrm{HCV}$ reactivation and hepatic enzyme flare ( $p$ $<0.001)$ (table 5).
Only 3 patients (37.5\%) form those who developed hepatic enzyme flare stopped their chemotherapy, while none from the other group stopped chemotherapy, there is a statistical significant difference $(\mathrm{p}=0.002)($ table 4$)$.

In this study the overall survival and disease-free survival in the three patients groups were comparable, although many patients among the HCV infected NHL group showed some delay in the treatment schedule, but this follow up was short (figure 2).

In the terms of overall response, $63 \%$ of our patients achieved complete response (CR) and $28 \%$ partial response (PR); $76 \%$ of DLBCL (30/39) patients obtained a CR, while between indolent NHL patients $21 \%$ (3/14 patients) achieved CR. While, among HCV positive NHL, $73.3 \%$ (11/15 patients) of DLBCL achieved CR, whereas, $33.3 \%$ (3/9 patients) of an indolent NHL achieved CR (p-value $=0.07)$. 
Table (1): Patient characteristics of the studied groups.

\begin{tabular}{|c|c|c|c|c|c|}
\hline \multicolumn{2}{|l|}{ 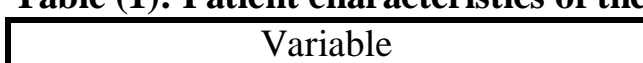 } & \multicolumn{2}{|c|}{ HCV positive patients } & \multirow{2}{*}{$\begin{array}{l}\text { HCV negative } \\
\text { patients } \\
\text { Group C (33) } \\
\text { No }(\%) \\
\end{array}$} & \multirow{2}{*}{ p-value } \\
\hline & & \multirow{2}{*}{$\begin{array}{c}\text { Received } \\
\text { Ribavirin } \\
\text { Group A (11) } \\
\text { No }(\%) \\
45+15.9\end{array}$} & \multirow{2}{*}{$\begin{array}{c}\text { Without } \\
\text { Ribavirin } \\
\text { Group B (13) } \\
\text { No }(\%) \\
52+6.5\end{array}$} & & \\
\hline Age (years) & Mean + SD & & & $49+13.7$ & 0.496 \\
\hline \multirow{2}{*}{ Sex } & Male & $6(54.5 \%)$ & $5(38.5 \%)$ & $19(57.7 \%)$ & \multirow[b]{2}{*}{0.50} \\
\hline & Female & $5(45.5 \%)$ & $8(61.5 \%)$ & $14(42.4 \%)$ & \\
\hline \multirow[t]{2}{*}{ PS } & $\mathrm{PS}=0,1$ & $10(90.9 \%)$ & $11(84.6 \%)$ & $29(87.9 \%)$ & \multirow[b]{2}{*}{0.895} \\
\hline & $\mathrm{PS}=2$ & $1(9.1 \%)$ & $2(15.4 \%)$ & $4(12.1 \%)$ & \\
\hline \multirow[t]{3}{*}{ Clinical } & LN(only) & $7(63.6 \%)$ & $6(46.2 \%)$ & $20(60.6 \%)$ & \multirow{3}{*}{0.424} \\
\hline & Splenomegaly & $3(27.3 \%)$ & $5(38.5 \%)$ & $5(15.2 \%)$ & \\
\hline & Extranodal & $1(9.1 \%)$ & $2(15.4 \%)$ & $8 \quad(24.2 \%)$ & \\
\hline \multirow[t]{4}{*}{ Stage } & $\mathrm{I}$ & $0(0 \%)$ & $1(7.7 \%)$ & $4(12.1 \%)$ & \multirow{4}{*}{0.224} \\
\hline & II & $2(18.2 \%)$ & $3(23.1 \%)$ & $15(45.5 \%)$ & \\
\hline & III & $4(36.4 \%)$ & $6(46.2 \%)$ & $9(27.3 \%)$ & \\
\hline & IV & $5(45.5 \%)$ & $3(23.1 \%)$ & $5(15.2 \%)$ & \\
\hline \multirow[t]{2}{*}{$\mathrm{LDH}$} & Normal & $0(0 \%)$ & $0(0 \%)$ & $2(6.1 \%)$ & \multirow[t]{2}{*}{0.471} \\
\hline & $\operatorname{High}(>234)$ & $11(100 \%)$ & $13(100 \%)$ & $31(90.9 \%)$ & \\
\hline \multirow[t]{4}{*}{ IPI } & Low risk & $1(9.1 \%)$ & $3(23.1 \%)$ & $11(33.3 \%)$ & \multirow{4}{*}{0.572} \\
\hline & Low-intermediate risk & $8(72.7 \%)$ & $8(61.5 \%)$ & $18(54.5 \%)$ & \\
\hline & High intermediate risk & $2(18.2 \%)$ & $2(15.4 \%)$ & $3(9.1 \%)$ & \\
\hline & High risk & $0(0 \%)$ & $0(0 \%)$ & $1(3.0 \%)$ & \\
\hline \multirow[t]{6}{*}{ Pathology } & DLBCL & $8(72.7 \%)$ & $7(53.8 \%)$ & $24(72.7 \%)$ & \multirow{6}{*}{0.130} \\
\hline & $\begin{array}{l}\text { Indolent NHL } \\
\text { - marginal zone } \\
\text { lymnhoma }\end{array}$ & $\begin{array}{c}3(27.3 \%) \\
1(9 \%)\end{array}$ & $\begin{array}{l}6(46.2 \%) \\
2(15.3 \%)\end{array}$ & $\begin{array}{c}5(15.2 \%) \\
0(0 \%)\end{array}$ & \\
\hline & $\begin{array}{l}\text { - small lymphocytic } \\
\text { lymphoma }\end{array}$ & $0(0 \%)$ & $3(23 \%)$ & $4(12.1 \%)$ & \\
\hline & - Mantle cell lymphoma & $1(9 \%)$ & $1(7.6 \%)$ & $1(3 \%)$ & \\
\hline & $\begin{array}{l}\text { - Lymphoplasmacytic } \\
\text { lymphoma }\end{array}$ & $1(9 \%)$ & $0(0 \%)$ & $0(0 \%)$ & \\
\hline & Burkitt & $0(0 \%)$ & $0(0 \%)$ & $4(12.1 \%)$ & \\
\hline \multirow[t]{4}{*}{ Chemotherapy } & CHOP & $8(72.7 \%)$ & $7(53.8 \%)$ & $24(72.7 \%)$ & \multirow{4}{*}{0.165} \\
\hline & $-\mathrm{COP}$ & $3(27.3 \%)$ & $5(38.5 \%)$ & $5(15.2 \%))$ & \\
\hline & -HyperCVAD & $0(0 \%)$ & $0(0 \%)$ & $4(12.1 \%)$ & \\
\hline & $-\mathrm{FC}$ & $0(0 \%)$ & $1(7.7 \%)$ & $0(0 \%)$ & \\
\hline
\end{tabular}

LN = Lymphadenopathy, DLBCL =diffuse large B-cell lymphoma, IPI = International Prognostic Index 
Table (2): Frequency of hepatic enzyme flare among the three studied groups .

\begin{tabular}{|c|c|c|c|c|}
\hline \multirow{3}{*}{ Enzyme flare } & \multicolumn{2}{|c|}{ HCV positive patients } & \multirow{2}{*}{$\begin{array}{c}\mathrm{HCV} \text { negative } \\
\text { patients }\end{array}$} & \multirow{3}{*}{$\mathrm{P}$ value } \\
\hline & \multirow[t]{2}{*}{$\begin{array}{c}\text { Received } \\
\text { Ribavirin } \\
\text { Group A (11) }\end{array}$} & $\begin{array}{c}\text { Without } \\
\text { Ribavirin } \\
\text { Group B (13) }\end{array}$ & & \\
\hline & & No $\quad(\%)$ & No $\quad(\%)$ & \\
\hline No enzyme flare & 72.7 & 69.2 & 97 & $0.019 *$ \\
\hline With enzyme flare & 27.3 & 30.8 & 1 & \\
\hline
\end{tabular}

Table (3): Comparison between HCV positive patients who received ribavirin (group A) versus those who did not receive ribavirin (group B) regarding hepatic enzyme flare \& $\mathrm{HCV}$ PCR reactivation

\begin{tabular}{|c|c|c|c|c|c|}
\hline \multirow[t]{3}{*}{ Variable } & \multicolumn{4}{|c|}{ HCV positive patients } & \multirow{3}{*}{$\mathrm{P}$ value } \\
\hline & \multicolumn{2}{|c|}{ Received Ribavirin (11) } & \multicolumn{2}{|c|}{ Without Ribavirin(13) } & \\
\hline & No & $(\%)$ & & (\%) & \\
\hline \multirow{2}{*}{$\begin{array}{l}\text { Enzyme flare: } \\
\text {-No } \\
\text {-Yes }\end{array}$} & 8 & 72.7 & 9 & 69.2 & \multirow{2}{*}{0.605} \\
\hline & 3 & 27.3 & 4 & 30.8 & \\
\hline \multirow{2}{*}{$\begin{array}{l}\text { PCR reactivation: } \\
\text { No } \\
\text { Yes }\end{array}$} & 9 & 81.8 & 10 & 76.9 & \multirow[t]{2}{*}{0.585} \\
\hline & 2 & 18.2 & 3 & 23.1 & \\
\hline
\end{tabular}

Table (4): Frequency treatment disruption among the studied groups of patients according to hepatic enzyme flare

\begin{tabular}{|l|cc|cc|c|}
\hline \multirow{2}{*}{ Variable } & \multicolumn{3}{|c|}{ Hepatic enzyme flare } & \multirow{2}{*}{ P value } \\
\cline { 2 - 5 } & \multicolumn{2}{|c|}{ No enzyme flare(49) } & \multicolumn{2}{|c|}{ With enzyme flare(8) } & \\
No & $(\%)$ & No & $(\%)$ & \\
\cline { 1 - 5 } $\begin{array}{l}\text { Chemotherapy course: } \\
\text {-completed }\end{array}$ & 49 & 100 & 5 & 62.5 & \multirow{2}{*}{$0.002 *$} \\
\cline { 1 - 5 } -stopped & 0 & 0 & 3 & 37.5 & \\
\hline
\end{tabular}

Table (5): Relation between HCV PCR reactivation in NHL patients with HCV positive and hepatic enzyme flare:

\begin{tabular}{|c|c|c|c|c|c|}
\hline \multirow[t]{3}{*}{ VARIABLE } & \multicolumn{4}{|c|}{ HCV POSITIVE NHL PATIENTS } & \multirow[t]{3}{*}{ P VALUE } \\
\hline & \multicolumn{2}{|c|}{$\begin{array}{c}\text { No HCV PCR } \\
\text { reactivation }(\mathrm{N}=19)\end{array}$} & \multicolumn{2}{|c|}{$\begin{array}{l}\text { With } \mathrm{HCV} \text { PCR } \\
\text { reactivation }(\mathrm{N}=5)\end{array}$} & \\
\hline & No & $\%$ & & $\%$ & \\
\hline \multirow{3}{*}{$\begin{array}{l}\text { Enzyme flare: } \\
\text {-No } \\
\text {-Yes }\end{array}$} & & & & & \multirow{3}{*}{$<0.001 *$} \\
\hline & 17 & 89.5 & 0 & 0 & \\
\hline & 2 & 10.5 & 5 & 100 & \\
\hline
\end{tabular}


Table (6): Distribution of treatment response among the studied groups of patients according to HCV status

\begin{tabular}{|c|c|c|c|c|c|c|c|}
\hline \multirow[t]{3}{*}{ Response } & \multicolumn{4}{|c|}{ HCV positive patients } & \multirow{2}{*}{\multicolumn{2}{|c|}{$\begin{array}{c}\mathrm{HCV} \text { negative } \\
\text { patients }\end{array}$}} & \multirow[t]{3}{*}{$P$ value } \\
\hline & \multicolumn{2}{|c|}{$\begin{array}{c}\text { Received } \\
\text { Ribavirin } \\
\text { Group A (11) }\end{array}$} & \multicolumn{2}{|c|}{$\begin{array}{c}\text { Without } \\
\text { Ribavirin } \\
\text { Group B (13) }\end{array}$} & & & \\
\hline & & $(\%)$ & & $(\%)$ & No & & \\
\hline $\begin{array}{l}\text { Responders } \\
\text {-Complete }\end{array}$ & 8 & 72.7 & 6 & 46.2 & 22 & 66.7 & \\
\hline Non-responders & 3 & 27.3 & 7 & 53.8 & 11 & 33.3 & 0.329 \\
\hline -Partial & 3 & 27.3 & 5 & 38.5 & 8 & 24.2 & \\
\hline -Stable & 0 & 0.0 & 1 & 7.7 & 3 & 9.1 & \\
\hline -Progression & 0 & 0.0 & 1 & 7.7 & 0 & 0.0 & \\
\hline Total & 11 & 100 & 13 & 100 & 33 & 100 & \\
\hline
\end{tabular}

Figure (2): One year disease-free survival

\section{Survival Functions}

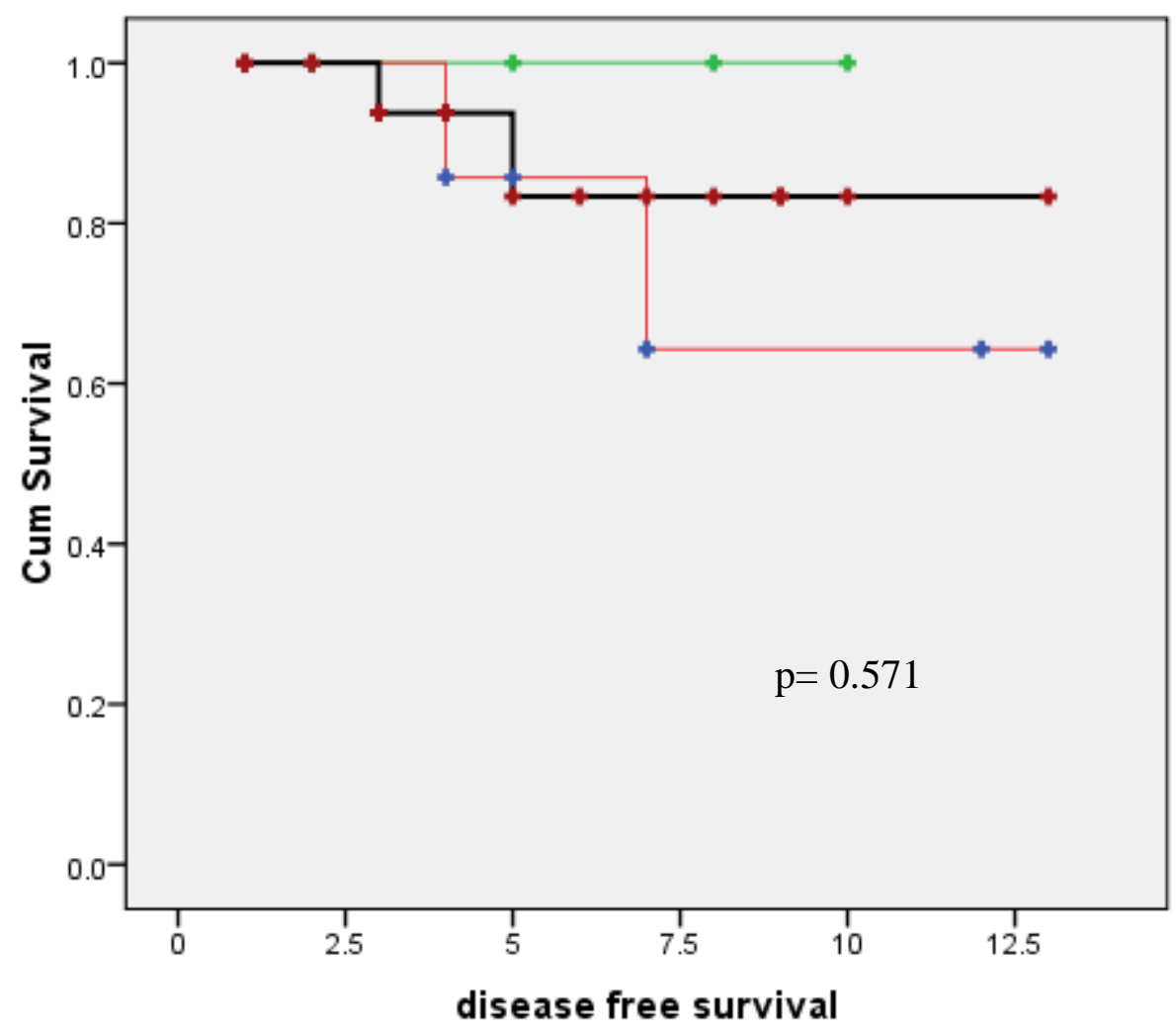

group
$\neg A$
$\neg 3$
+ A-censored
+ B-censored
+ C-censored 


\section{DISCUSSION}

The percentage of $\mathrm{HCV}$ infection among $\mathrm{B}$ cell NHL patients is $42 \%$ ( 24 out of 57 cases) which is in agreement with and equal to results obtained by Cowgill et al.[10] (a study conducted at Cairo University hospitals, Egypt on 220 patients and the prevalence of $\mathrm{HCV}$ infection was $42.7 \%$ ), while Coppola et al. [11] (a study conducted in Italy on 36 patients and the prevalence of $\mathrm{HCV}$ infection was 22 $\%)$.

The interesting finding in our study is that percentage (42\%) of HCV infection which is higher than that observed in the general population (15-20\%) [12]. This comes in agreement with Nosotti et al. [3], who stated that the prevalence of $\mathrm{HCV}$ infection among NHL patients was $9.2 \%$, this prevalence is also higher than that observed in the general population in Italy (3\%). This association between B cell non-Hodgkin lymphomas (NHL) and HCV infection may be related to chronic antigenic stimulation of $\mathrm{HCV}$.

In this study, the comparison between HCV positive patients versus HCV negative patients with NHL showed no statistically significant difference as regard age, sex, clinical presentation, stage, IPI score, PS status, ,LDH level, pathological type, chemotherapy regimen, this comes in concordance with results of Marignani et al.[13]. Most of our HCV positive patients $(75 \%)$ presented with advanced stage (III/IV) compared to $42.5 \%$ among HCV negative patients (p-value $=0.09$ ), this result was similar to the study of Luppi et al.[14] who reported that the percentage of advanced stage (III/IV) was $74 \%$ of $\mathrm{HCV}$ positive patients, while $64 \%$ of $\mathrm{HCV}$ negative patients.

In the present study, 14 patients $(24.5 \%)$ had an indolent NHL and 43 patients (75.4\%) had an aggressive NHL. The most frequent pathological type was DLBCL. The highest percentage $(37.5 \%)$ of Indolent NHL type was found among HCV positive NHL cases (9/24 patients), especially marginal zone lymphoma (3 patients). This result is in concordance with Arcaini et al. [1] who reported that $37 \%$ of $\mathrm{HCV}$ positive NHL cases (59/160 patients) had an indolent NHL type, while $62 \%$ of the cases had a DLBCL type.
In the terms of overall response, $63 \%$ of our patients achieved complete response (CR) and $28 \%$ partial response (PR); $76 \%$ of DLBCL (30/39) patients obtained a CR, while between indolent NHL patients $21 \%$ (3/14 patients) achieved CR. While, among HCV positive NHL, $73.3 \%$ (11/15 patients) of DLBCL achieved CR, whereas, 33.3\% (3/9 patients) of an indolent NHL achieved CR (pvalue $=0.07)$. While, Pellicelli et al. [15] showed that $54 \%$ of DLBCL achieved CR and $55 \%$ of indolent NHL patients achieved CR. In our study, no statistically significant difference was found when we compared the $\mathrm{CR}$ rates in the three groups.

Among the 57 NHL patients in our study, patients (14\%) developed hepatic enzyme flare. The highest percentage of enzymatic flare was among HCV infected patients (29.2 $\%$ ), while only one patient (3\%) in the HCV negative group (C). There was a statistical significant difference $(p=0.007)$ between the two groups. This result comes in agreement with another study which reported that among the HCV-infected subjects, the incidence of hepatitis flares was $26.3 \%$ vs $2.1 \%$ among the HCV-uninfected individuals [3].

We found that $20.8 \%$ of HCV infected NHL patients (5/24 patients) developed HCV PCR reactivation. Also, Parag et al [5] reported that $36.3 \%$ of $\mathrm{HCV}$ infected NHL patients proved by PCR (8/22 patients) developed HCV PCR reactivation. While, Boyle et al. [16] reported that $66.6 \%$ of $\mathrm{HCV}$ infected NHL patients(6/9 patients) developed HCV PCR reactivation. This difference between our study and other studies regarding the percentage of hepatic enzyme flare and HCV PCR reactivation can be explained by (1) difference in the definition of hepatic enzyme flare and HCV PCR reactivation between studies (2) different sample size (3) heterogeneity of the histopathology [1] (4) difference in chemotherapy regimens and the use of rituximab (5) different HCV genotype and association with other viral infection (HBV or HIV) (6) difference in duration of chronic $\mathrm{HCV}$ infection and the risk of developing cirrhosis.

In our study there was a significant relation between HCV reactivation and hepatic enzyme flare ( $p<0.001$ ), also Parag et al. [5] agree 
with our result, in contrary to Marignani et al. [13] who found no significant relation $(\mathrm{p}=0.8)$.

Regarding the toxicities (apart from hepatic toxicity), they were similar in all groups ; there were no statistically significant differences, with only one patient developed Grade 4 anemia in group A ( the intervention arm who received ribavirin) but without significant difference

comparing to other groups $(\mathrm{p}=0.58)$. The hematologic toxicity with the use of ribavirin was to some extent accepted.

In this study the overall survival and diseasefree survival in the three patients groups were comparable, although many patients among the HCV infected NHL group showed some delay in the treatment schedule, but this follow up was short.

\section{Conclusion,}

Frequency of $\mathrm{HCV}$ infection in patients with B cell NHL is higher than in the general population. Acute exacerbation and reactivation of chronic $\mathrm{HCV}$ infection occur in a sizeable subset of patients with NHL during chemotherapy.The use of ribavirin did not decrease hepatic enzyme flare or HCV PCR reactivation during chemotherapy, also ribavirin did not affect response to chemotherapy or survival rates.

\section{Funding: None}

Conflicts of interest: The authors declare that there is no conflict of interest.

Ethical approval: approved.

\section{REFERENCES}

1. Arcaini Lc, Merli M, Passamonti F, Bruno R, Brusamolino E, Sacchi $\mathrm{P}$, et al. Impact of treatment-related liver toxicity on the outcome of HCV-positive non-Hodgkin's lymphomas. Am J Hemato 2010;85 (1):4650 .

2. Torres H, Davila M. Reactivation of hepatitis $B$ virus and hepatitis $C$ virus in patients with cancer. Nat Rev Clin Oncol 2012;9(3):156166.

3. Nosotti L, D'Andrea M, Pitidis A, Pimpinelli F, Dessanti M, Pisani F et al. Hepatitis C virus infection prevalence and liver dysfunction in a cohort of Bcell nonHodgkin's lymphoma patients treated with immunochemotherapy. Scand J Infect Dis 2012;44(1):70-73.
4. Pitini V, Sturniolo G, Arrigo C, Leonardi S, Pino S, Altavilla G. HCV genotype 2 as a risk factor for reactivation in patients with Bcell lymphoma undergoing rituximab combination chemotherapy. $\mathrm{Br} J$ Haematol 2010;150:116-118.

5. Parag M, Dimitrios P, Roy F, Ying J, Jessica $\mathrm{P}$, Davila $\mathrm{M}$ et al. Acute exacerbation and reactivation of chronic hepatitis $\mathrm{C}$ virus infection in cancer patients. Journal of Hepatology 2012; 57: 1177-1185.

6. Yang D, Roberts L. Assessment of Liver Function and Viral Hepatitis for the Medical Oncologist. ASCO educational book2010;142-147

7. Heid C, Stevens J, Livak, J, Williams, P. Real time quantitative PCR. Genome Research 1996; 6: 986-94.

8. McGovern B, Birch C, Bowen M, Reyor L, Nagami E, Chung R, et al. Improving the diagnosis of acute hepatitis $\mathrm{C}$ virus infection with expanded viral load criteria. Clin Infect Dis 2009;49:1051-1060.

9. Eisenhauer E, Therasse P, Bogaerts J, Schwartz L, Sargent D, Ford R et al. New response evaluation criteria in solid tumours: Revised RECIST guideline (version 1.1). European Journal of Cancer 2009; 45:228- 247

10. Cowgill K, Eissa S, Mokhtar N, Loffredo C, Abdel-Hamid M, Fahmy A, et al. Casecontrol study of non-Hodgkin's lymphoma and hepatitis $\mathrm{C}$ virus infection in Egypt. Int $J$ Epidemiol 2004 ;33:1034-1039.

11. Coppola N, Pisaturo M, Guastafierro S, Tonziello G, Sica A, Iodice $\mathrm{V}$, et al. Increased hepatitis $\mathrm{C}$ viral load and reactivation of liver disease in $\mathrm{HCV}$ RNApositive patients with oncohaematological disease undergoing chemotherapy. Dig Liver Dis 2012;44 (1):49-54.

12. Frank $\mathrm{C}$, Mohamed $\mathrm{K}$, Strickland $\mathrm{T}$, Lavanchy D, Arthur R, Magder L, et al. The role of parenteral antischistosomal therapy in the spread of hepatitis $\mathrm{C}$ virus in Egypt.Lancet 2000;355:887-91.

13. Marignani M, Mangone M, Cox M, Angeletti S, Veggia B, Ferrari A, et al. HCV-positive status and hepatitis flares in patients with Bcell non-Hodgkin's lymphoma treated with rituximab containing regimens. Dig Liver Dis 2011;43:139-42. 
14. Luppi M, Longo G, Ferrari M, Barozzi P, Marasca R, Morselli M, et al. Clinicopathological characterization of hepatitis $\mathrm{C}$ virus-related B-cell non-Hodgkin's lymphomas without symptomatic cryoglobulinemia. Ann Oncol 1998 ; 9:49598.

15. Pellicelli A, Marignani M, Zoli V, Romano M, Morrone A, Nosotti L, et al. Hepatitis C virus-related B cell subtypes in non Hodgkin's lymphoma. World J Hepatol 2011; 3(11): 278-284.
16. Boyle F, Reid E. Viral reactivation and clinical hepatitis in patients with hepatitis $\mathrm{C}$ who receive rituximab as part of chemotherapy for treatment of lymphoma: A case series. J Clin Oncol 2010;28,(suppl; abstr e18559). 